\title{
Social Transactions or Christian Ministry?: International and Customary Adoption in Vanuatu
}

\author{
Kenneth Nehrbass and Daniel Nehrbass
}

\begin{abstract}
The recent surge of Western interest in international adoption has arrived in the South Pacific. Yet the Christian faith, despite disparate views about adoption, has required both expatriate and Melanesian families to consider, or sometimes reconsider, their own parameters for the adoption or placement of children. Orphan care has become a top social issue especially for Christians in recent decades. However, international adoptions are costly in terms of time and money, and are often at the nexus of these diverging values and conceptualizations. All parties involved can find the process frustrating and disillusioning, even if the end goal is noble and satisfying. In fact, adoption "as a norm" in Vanuatu can positively shape western understandings of adoption. In some ways, ni-Vanuatu conventions regarding jural inclusivity and exchange are closer to biblical ideas of family, kinning, and adoption. This article should familiarize people from "receiving countries" with customary adoption in the Pacific, and should help Melanesians understand the hurdles involved in international adoption. Hopefully, a path can be forged for international adoptions to be arranged such that the best interest of all parties is served.
\end{abstract}

\section{Introduction}

"I would like you to adopt our youngest son. Doing so would cement our relationship,” John, a ni-Vanuatu pastor suggested to his long-term missionary friend George Chesterton. On the one hand, George and Briana, who came from the USA to serve as Bible translators on Tanna Island, found John's offer to be flattering and even tempting. Yet they realized that expatriate adoption also presented a number of difficulties. While adoptions are arranged on Tanna to forge meaningful relationships, for Americans, taking in a ni-Vanuatu child would involve jumping through legal hoops, filing immigration papers, and saving for the child's college tuition and other costs of raising a child in the USA. But more significantly, the Chestertons have deeply embedded cultural norms which tell them that, in general, only orphans are eligible for adoption. George argued that a biological mother and father should raise the child God gave them. "Besides, what would that child feel when she got older about why mom and dad sent her off to be with these white people? And when we did make visits back to Tanna, how would she be received, and how would she relate to her biological parents?"

Chesterton was expressing a primary concern about what Howell (2003) has called "kinning"-the process of making an adoptee into a relative. How will a niVanuatu adolescent adjust her personhood as she balances her ethnic identity with her fictive social identity (466)? In an absence of shared history how will she become part of her biological family (472)? All of the westerners I (Kenneth) interviewed in this study, including Chesterton, consider the process of adoption to be sufficiently disruptive that it should be reserved only for those who "really need it." They also all saw adoption as a way of living out their Christian faith. Yet in Melanesia, adoption-including expatriate adoptionis generally considered to be a desirable social transaction, and is emblematic of their animistic religious background.

\footnotetext{
${ }^{\prime}$ We should mention, however, that many Americans recognize the noble choice of a birthmother to place her infant with another family for whatever reason she deems valid. For many Christians, adopting out a child is preferable to abortion; and the reasons that a birth mother has for placing a child up for adoption are rarely questioned. By extension, perhaps one can assume that women in other countries can also be entrusted with the same capacity.
} 


\section{Purpose of the Study}

Having worked in Vanuatu from 2002 to 2012, I (Kenneth) observed several ni-Vanuatu approach expatriates to propose transactions in international kinship. These stories of expatriate involvement in adoption reveal a vast disconnect between Western and kastom (traditional) conceptualizations of adoption and fosterage. They also call into question theological questions about the role biological parents should play in raising their children. The purpose of this research is to understand the ways in which Westerners differ from Melanesians on the topic of adoption so that future transactions in kinship can be positive, enduring and biblically sound.

\section{Research Methods}

In addition to prolonged observations in the field, my colleague Daniele Smith and I (Kenneth) interviewed ten ni-Vanuatu families who were willing to participate in a study of divergent practices in adoption on these the islands of Tanna and Rah in Vanuatu. ${ }^{2}$ I also interviewed three expatriate families who lived long term in Vanuatu, and who successfully adopted children from there. As we analyzed the data from the interviews, we discovered some emergent themes that describe the discourse of "kastom" adoption as well as "expatriate adoption.”

\section{Significance of the Study}

Westerners-often with one or more birth children-are increasingly aware of what Elliott (2012) has termed a "global orphan crisis". Orphan care has become a top social issue especially for Christians in recent decades, and the interest appears to have significant staying-power (D. Nehrbass 2012, 18). Yet a conflicting message is also prevalent. Visitors to orphanages abroad often discover that many of the children are not legally available for adoption. This raises the challenge that not all children who are colloquially referred to as "orphans" are actually in need of a new permanent family, thus making the scope of the orphan crisis difficult to gauge. This article broadens, socially and theologically, the terms orphan and adoption, to demonstrate the multifaceted nature of fictive kinship.

\footnotetext{
${ }^{2}$ In the interest of confidentiality, all names are pseudonyms.
}

\section{Findings}

While some families in Vanuatu adopt children for practical reasons (aging grandparents need a helper, or a couple is infertile), many ni-Vanuatu prefer to arrange kastom adoptions precisely because such practices embody local ethno-linguistic identities. Adoption has become a symbol of kastom itself. And embracing kastom in a post-colonial setting is a way of asserting identity and agency (Tonkinson 1982). So adoption in Melanesia is not as much about reproduction of the family as it is about asserting agency (Brady 1976; Carroll 1970; 2008, 155; Goody 1969). As one woman from Rah Island put it, "Adoption is good because it is a practice that dates from long ago" (Smith 2012, 7). For those who participated in this research study, adoption is about being "man Rah", or being "man Tanna." Within kastom, it is every bit as natural to exchange children with close family members as it is to cook taro, forge a canoe, or speak a vernacular. These are all indicative of what it means to be a person from Vanuatu.

\section{Adoption on Rah}

Anthropologists have disagreed about the extent of influence that birth parents have in the lives of adoptive children in the Banks Islands (including Rah). Rivers (1914) argued that birth parents had essentially no meaning in Mota and other Banks islands. Much later, Scheffler (1970) argued that birth parents obviously have a great influence on their biological children. Perhaps the disjunction between Rivers and Scheffler can be explained through a cultural shift over the decades, partially due to Christianization and Westernization. With the movement away from strict non-disclosure, biological parents are increasingly asserting themselves. One mother, Vivian, became upset on several occasions with how the adoptive family, the Dengs, disciplined her biological child. Vivian's family required the Dengs to make reparation with a pig and cash (Smith 2012, 12).

Adoptive relationships are common in Rah. Of the ten families interviewed in 2012, seven had adoptive children, and five of the ten had more than one adoptive child (Smith 2012, 1). In one case, the maternal grandparents adopted a child, similar to the practice on Tanna Island of returning a child to the wife's parents, since a human being (i.e., the wife) has been removed from the clan. Many other social relationships permit a family to instigate adoption.

In two cases on Rah, the adoption was arranged when the child had lost at least one parent. One case 
involved infertility. One child was adopted out because of a "taboo relationship." In other cases, the ostensible reason for adoption was that the prospective parents "saw the child and liked him." Fena, the youngest of the Wolon family, was adopted by an infertile couple. When the couple heard about Fena's birth, they sent an intermediary to negotiate an adoption. Fena's father was not interested, but her mother felt empathetic toward the infertile couple, and eventually persuaded the father. When Fena was two months old, the infertile couple carried out the kastom rites to obtain custody of the girl (Smith 2012, 12).

While adoption is enthusiastically touted as a way to perpetuate kastom, it is also accompanied by more negative discourse. Smith noted that five of the ten couples she interviewed offered negative feelings about adoption. Some feared that the adoptive children did not receive the same level of care as other children. Others decried that the divvying up of land through adoptive relationships imperiled their own access to resources.

\section{International Adoption on Rah}

Expatriate adoption has reached the Banks Islands. Smith (2012) also observed two cases where adoptions involved both kastom and the national legal system. An Australian couple is in the process of adopting two children; and a Caucasian politician with Vanuatu citizenship arranged an adoption from there as well. Working within the kastom framework in addition to the legal system illustrates how nuanced adoption can be, and how adoption is at the nexus of the legal system, as cultural identity and religious identity.

\section{Adoption On Tanna}

The term on Tanna island for "adopt" is a transitive verb which literally means "to yank; to pull down" as in "to yank a tooth" or "to pick a mandarin." It connotes the initial difficulty-or even pain-in taking a child away; she does not depart without some tugging. More significantly, Tannese do not use the more common verbs "give" or "take/carry" for adoption, as they would with other exchanges. The discourse of adoption also contains many other metaphors and indirect locutions: "She is watching/caring for him;" "He lives with them;" or "She breastfeeds him." The practice of "child exchange" also falls under the more general rubric of "exchanging/returning/avenging" which is the same term for the movement of women in marriage.

Other cases of adoption may seem like more familiar cases of adoption to expatriates: In the case of infertility, the male's classificatory brother may adopt out one of his own sons (typically not the firstborn) to the infertile couple. And in the case of a mother's death during pregnancy, the newborn is adopted out to the wife of a classificatory brother who is still nursing.

As with Rah, adoption is also common on Tanna. For example, around $67 \%$ of the males in Yanemilen village between the ages 30 and 50 had adopted a child either in or out by 2012 .

The exchange of children is the modal type of adoption. In terms of frequency, exchanges among siblings, or "gifted" adoptions that are arranged purely to increase social bonds involved seven cases. The other eight cases involved collectively: death, illegitimate children, or infertility.

\section{Adoption due to Death}

Kata's wife Nalpao died in childbirth, triggering Kata to find a wet nurse. He decided to adopt out his son Pita Job to his paternal grandfather's brother's grandson, Tion. Tion's wife Naka, who had just given birth to a daughter, Rachel, so she could also nurse baby Job. Note that Job was raised by Tion and Naka, but there was no transfer of land, because Kata and Tion both lay claim to the land that belonged to their shared great-grandfather. Keeping the land in the family informs who will be asked to serve as a wet nurse for a child.

In some cases, when a mother dies after childbirth, the child will then go live with an in-law ( +1 generation). Jonny's wife Yaulko died, so he sent baby Linda back to her mother's parents, Nowiwə and Nakiə. Being a girl, there was no discussion of land rights in Linda's transfer.

\section{Adoption due to Infertility}

Nasara and his wife Naulin are infertile. Nasara's paternal grandfather's grandson (by a previous wife) is Napiko. Napiko and his wife Esta had five children, and adopted out their youngest son Joseph to Nasara and Naulin. The gift may be reciprocated much later. For example, Napiko told me that when Joseph marries and has several children, he may adopt out one of his own daughters to care for Napiko and Esta in their old age.

The genogram below (Figure 1) shows the adoptive ties created among several nuclear families due to infertility and death. 
Figure 1 Adoptive Ties in Yanemilen, Tanna

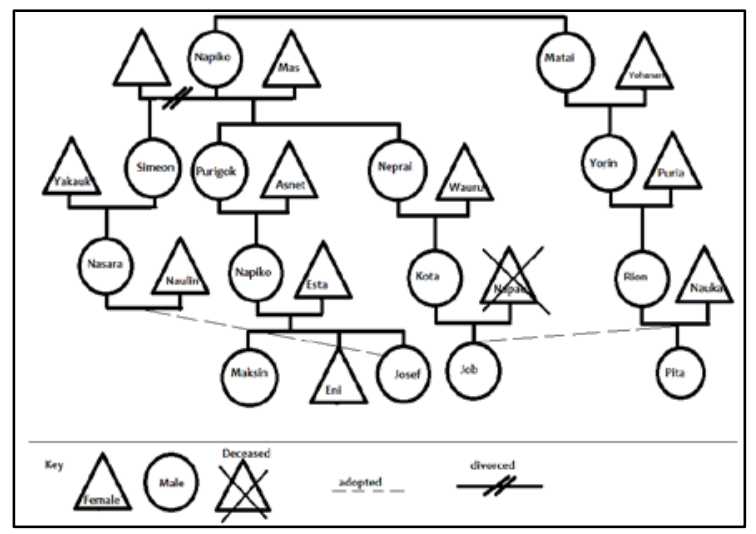

Adoption due to "Taboo Relationships"

In contrast to a prototypical kastom adoption, the commitment to care for children born out of a "taboo relationship" is not accompanied by speeches, land, exchanges of crops and mats. Instead, custody is given through an informal relationship, with more plasticity in the rites and rights. Linda left her husband, but had two children by him: Roy and Vini. Linda surrendered her boy Roy, sending him to live with her brother Nowa. But Linda continued to care for her daughter Vini. Later, when Linda began cohabiting with Tom, Tom became the de facto foster father of Vini.

\section{A Theological Critique of Six Variables of Adoption in Vanuatu}

As we compared adoption in two settings in Vanuatu, we focused on six variables of adoption that seem particularly pertinent to the global discussion of the placement of children: Disclosure, jural inclusivity, land rights, permanence, reciprocation, and the exchange of goods. We show below that these six variables embody idiosyncratic adoptive situations throughout Vanuatu. But more significantly, the adoption norms are so divergent from international adoption that the two institutions remain largely incompatible with each other. Adoption through the courts in Vanuatu is one thing; kastom adoption is another convention all together.

\section{Disclosure}

Is adoption shameful? Should it be secretive? Adoption conventions vary widely in terms disclosure. Participants on Rah described the ideal kastom adoption as an arrangement carried out when the adoptee is still an infant, so that she will not know her birth parents. The version of kastom on Rah imposes fines of pigs and cash on anyone who subsequently discloses the names of the biological parents. "It could even happen that someone, usually the adoptive family, would pay a kleva [diviner] . . . to 'poison' the informer, causing his death by black magic" (Smith 2012, 3). Participants on Rah indicated that the secrecy was necessary for averting potential jealousies or disputes over inheritance.

Two participants on Rah indicated that the highly secretive nature of adoption is amag (antiquated). This cultural innovation of openness also means the child may know his birth parents' identity. A shift toward openness challenges kastom sensibilities about respect. One participant learned of her birth parents' identity but "kept it secret until the death of her adoptive parents, out of respect for them" (Smith 2012, 3). A consequence of the recent willingness to openly identify the birthparents has been the antiquation of kastom fines for revealing the names of the birth parents. While there is a discourse of fining people for revealing the identity, the recent laxity toward secrecy rules has made it unlikely that any fine would actually be imposed.

On Tanna, however, adoption is usually arranged well after the child has been weaned; and the arrangements are quite open. Subsequently, the adoptees regularly visit their biological parents, and continue to call them "mother" or "father."

Disclosure has been a sensitive topic in Western nations. Until the 1980's, it was possible for adoptive parents to withhold the fact that their children were adopted from coworkers, extended family, and even their adopted children. Sometimes, this lack of disclosure was justified by saying it was better for children not to know. Today, that notion has been almost universally abandoned by child welfare workers. What's more, the hope of withholding such information has become a vain wish, with the advent of DNA testing websites and services.

Scripture also has a perspective on the sensitivity of adoption. In five instances, the New Testament highly esteems adoption by employing the use of hyiothesia as a metaphor to describe the relationship of the people of Israel to God (Rom 9:4) and our new identity in Christ (Schoenberg 1964, 51). Ephesians 1:5 claims, "he predestined us for adoption to sonship through Jesus Christ, in accordance with his pleasure and will" (NIV).

Romans 8:15 contrasts "slave to sin" with "adoption to sonship" through the Spirit. And Romans 8:23 compares our "adoption to sonship" to our regenerated bodies in the parousia. In these passages, adoption is not conceived of as a last resort, nor are the children abandoned or unwanted. To the contrary, Schooenberg argues that hyiothesia is primarily about fulfilling a promise to care for someone (55). Indeed, God's plan 
all along was to adopt us into His family. In fact, adoption is not only "disclosed" in this passage, it is celebrated!

Galatians 4:5 uses the same metaphor: Christ redeemed us "that we might receive adoption to sonship" (NIV). Mundhenk (2008) points out that in this passage, the connotation of hyiothesia is that the sons waited to be legally recognized as proper heirs (170). There would be disclosure-but in one sense, God's redeemed needed to wait until the proper time of disclosure.

This celebration of adoption-this disclosure of our true position as God's children-fits into a wider biblical principle of protection and nurturing, especially of the most vulnerable. As Miller (2015) pointed out, nature contains

clues to redemption and to God's own outreach to strangers, outcasts, the fatherless and motherless, and sinners. God calls the little creatures and implants within their instincts the tendency to care for and defend young who were not born to them nor even to their species. Then surely God has placed in the human heart the capability and desire to take a child by choice into the family relationship and make it one's own ... Adoption is not the exception; it is not strange or unusual. It is built into nature and has its roots in God's heart. God offers us, with arms wide open, a welcome into his family. (17-18)

Adoption is not an incidental metaphor in the Gospel: it is a central theme with multiple teaching angles: We are born into a natural family-a family of sin where our inheritance is death. But we are reborn into a new family and are given a new Father, a new name, and a new inheritance. The acceptance into our new family is permanent and has legal consequence: we are loosed from the curse and our debt is paid.

\section{Jural Inclusivity}

Jural inclusivity-sharing parental responsibilities between the biological and adoptive parents-raises concerns for Western Christians, especially when the adopted children may be raised by parents who are not believers. Therefore, missionaries often prohibited kastom adoption throughout Vanuatu, to ensure biological children of Christians were "equally yoked" (2 Cor 6:14) with Christian parents. In fact, Paul's use of adoption as a metaphor suggested a complete break from the "fleshly" family. Those who have been adopted do not have any further relationship with their former slavemaster! (Rom. 8:15). Note that while Roman adoption conventions may have involved emancipation from the biological father, some scholars think it is unlikely that adopting a slave would effectively change the status of the slave (Kim 2014). Paul, then is upending Roman conventions of adoption.

Obviously, if the identities of the biological parents are not disclosed, the parents cannot be overtly involved in the care of their child. Therefore, kastom adoptions on Rah require jural exclusivity, whereas Tanna's kastom adoptions-arranged in the open-involve a lifetime of jural inclusivity. Elma, a mother on Tanna, adopted out her daughter Wai; but Wai would return to her parents' hamlet for weeks or months at a time. The biological parents are often involved with the mundane and important aspects of life as the child grows up: They are expected to help pay for school fees, and are involved in selecting a spouse among eligible cross cousins.

In the United States, adoptions involving jural exclusivity are called "closed," and those with inclusivity are "open." Nearly all adoptions in the United States were "closed" until the 1980s. It was assumed by judges and child welfare workers that a closed arrangement was better for all parties-giving all parties closure and allowing them to move on with their new lives. That assumption has been largely abandoned as many children adopted in the $1960 \mathrm{~s}$ and $1970 \mathrm{~s}$ began searching for their biological families. This search has often been accompanied with testimonies of pain and longing. But with the advent of legalized abortion, adoption attorneys and agencies also needed a further promise to women facing crisis pregnancy that they had the option to be somewhat involved in the child's life if they placed the child for adoption.

In fact, open adoption is now the standard in the United States, and child welfare experts are in nearunanimous agreement about the benefit of this practice for adoptees. But with the arrival of $23 \& \mathrm{Me}$, Ancestry.com, and other such agencies the notion of closed adoption has become a vain hope anyway: Adopted children are finding their birth families through DNA testing even when their adoptions were closed.

Despite concerns about being unequally yoked, by the end of this article, it should be clear that the missionaries were in error to proscribe ni-Vanuatu from adopting out their children. Adoption is at the core of kastom. And Christian parents in Vanuatu have discovered that jural inclusivity allows them to continue to influence their biological children whom they have adopted out.

\section{Land rights}

In Vanuatu, kastom adoptions inevitably intersect with land rights and consequently naming (see Lindstrom 1985). Inheritances are traced patrilineally in both Rah and Tanna, and the land must be shared by classificatory brothers. Therefore, when an adoption 
is arranged, the classificatory brothers are stakeholders, and may have an interest in blocking the adoption for fear the land will not have the carrying capacity to sustain the addition of a family member.

On Tanna, ideally, a man would adopt out his son to one of his own brothers, so that there would be no future dispute over land. The son would continue to cultivate the same land as his brothers, regardless of whether he was raised by his biological father or paternal uncle (who is actually a classificatory father). A paternal uncle has the privilege of naming the boy at age one or two, further linking him to one of several plots of land traced through patrilineal descent.

However, adoptive relationships, in reality, are not always this clear cut. Families find themselves for one reason or another deviating from the ideal adoption norms in kastom. For example, a man in Imayo village adopted out a son, Ron, to his cross cousin in Isaka village. When Ron married, he began to cultivate the land of his adoptive brothers as if it were his own. Soon, some of these brothers argued that Ron had no right to cultivate their land. However, some of Ron's biological brothers also argued that he had no right to return to the biological brothers' land. It seems that the nature of full disclosure on Tanna foments such land disputes. If adoptions were arranged secretly at infancy, as they are ideally done in Rah, the adoptive family would be prohibited from disputing the son's legitimacy to the land, as a claim to land would require disclosing the boy's biological parents and kastom imposes heavy fines on those who let out the secret.

Many Americans recognize the right of inheritance as inextricable from the decree of adoption. Every US state confers the right of adopted children to inherit from their adoptive parents, and most states even confer the right of adoptive parents to inherit from their adopted children (Katz \& Katz, 2012). When my wife and I (Daniel) adopted one of our children, the judge asked for a verbal affirmation that we understood our adoptive children would have a right to inherit our property. This type of change in legal status is commonly referred to "as-if" status. Adopted children receive the rights they are due as if they were born into the family.

We do not have the space to get into the theology of land ownership in the Old and New Testaments, but Brueggemann's (2002) thesis is insightful when it comes to adoption and land permanence. God's works in history upend common sense notions of land ownership: When the people of God actively sought to obtain land, they lost it; when they were selfless, they received the land. Who could be more disenfranchised-more "un-landed"-than the legal orphan? When adopted children receive the gift of permanent land, they are living examples of how God turns worldly concepts of land and inheritance upside down.
It is also worth looking briefly at how Paul connects adoption and land permanence:

As long as an heir is underage, he is no different from a slave, although he owns the whole estate. The heir is subject to guardians and trustees until the time set by his father. ${ }^{3}$ So also, when we were underage, we were in slavery under the elemental spiritual forces of the world. 'But when the set time had fully come, God sent his Son, born of a woman, born under the law, ${ }^{5}$ to redeem those under the law, that we might receive adoption to sonship. Because you are his sons, God sent the Spirit of his Son into our hearts, the Spirit who calls out, "Abba, Father." So you are no longer a slave, but God's child; and since you are his child, God has made you also an heir. (Gal. 4:17, NIV)

While it is unclear how much adoption carried with it the legal status of inheritance in the Roman world (Kim 2014), Paul saw adoption as a fitting metaphor for the Christian's change in legal status with God, and of the way God's adoptive children possess an inheritance.

\section{Permanence}

Adoptions also vary in terms of permanency, and Christian theology also informs our understanding of the indissolubility of adoption.

Adoptive relationships on Rah, arranged in secret, are ideally permanent. There are, of course, less immutable arrangements where a child must live with a caretaker due to death of the parents, or when the child is born as the result of an extra-marital affair. These cases are not permanent and do not entail land rights, since land is still traced through patrilineal decent. It is also possible on Rah to reverse an adoption, and to reinstate the biologically-traced inheritance. The biological and adoptive parents must negotiate a price representative of the care that the adoptive parents have given to the child. Smith $(2012,4)$ noted that the Seton family adopted out an infant, but after a week they requested for him to be returned. The adoptive family returned the child and accepted a small payment as the terms for reconciliation.

While there is jural inclusivity and full disclosure of adoptions on Tanna, families expect the arrangement to be permanent. Adults who have been adopted refer to their adoptive parents (as well as all classificatory parents) as "mother and father", and to their biological parents as "straight mother/father." There are also the numerous cases of less-permanent arrangements for "fosterage" such as death or an illegitimate birth.

What is of particular interest about the permanency of adoption is that this is the one variable which especially resonates with international conventions. 
While adoption is conceived in many different ways throughout the world, a semantic sine qua non of adoption (and not fosterage) seems to be its permanence.

In the United States, social workers and family courts establish plans for children who enter foster care. These plans are called "permanency plans." In other words, the central value of child welfare is permanency. Whether the placement is permanently reunified with biological family, or with an adoptive family, the Western system reveres permanence.

The Apostle Paul underscored the permanence of adoption in his metaphor of redemption. In Romans 8:23 we read, "Not only so, but we ourselves, who have the firstfruits of the Spirit, groan inwardly as we wait eagerly for our adoption to sonship, the redemption of our bodies" (NIV). Such "redemption" was efficacious precisely because it was irrevocable.

\section{Reciprocation}

Reciprocation is an essential component of Melanesian logic (Trompf 1994). In Tanna, a gift of a child must be reciprocated at some point in the future. The open nature of adoption on Tanna allows for such reciprocation. If the names of the biological parents were kept secret, as they are on Rah, it would be impossible for outward displays of reciprocation to be the central focus of an adoption exchange.

While conducting fieldwork on Tanna, I (Kenneth) collected case studies where families exchanged children (either in or out) for various reasons. Participants indicated that they experience tremendous pressure to adopt out the firstborn girl and give her back to her mother's parents, so that she will provide care for them in their old age. There is also pressure, according to kastom, to exchange a son for a daughter (or vice versa) with siblings. These cases are also referred to as marpinien "exchanging"-the quintessential exchange in a reciprocity-based economy.

In contrast to the discourse of adoption practices at the international level, kastom adoption does not involve a discourse of "the child's best interests" nor particularly the parents' desire to fill the home with children or even out the sexes within the nuclear family -though four families used such discourse when they recounted their adoption stories. Instead, the main impetus for the exchange of children is the intense social pressure placed on families to reciprocate their most valuable "assets", thereby strengthening kinship ties. This social pressure comes in the form of chiefly speeches given in the nakamal (the village center, or kava drinking grounds). For example, Kami, a man in his mid-fifties, died after a long struggle with Chronic Obstructive Pulmonary Disease (COPD). He was survived by two unmarried daughters in their late teens

or early twenties. As the village and extended family met for the next several weeks to discuss the cause of Kami's death, a prevailing theme emerged: Kami had refused years earlier to adopt out one of his daughters into his mother-in-law's family, in reciprocation for his own wife. The scorned in-laws argued that this unreciprocated gift would continue to cause disaster unless the daughters married cross cousins in the mother-in-law's lineage. So while adoption can be a practical matter (placing a child in an infertile home, or finding a wet nurse for a recently orphaned child), more commonly the placement of children is a fundamental part of delineating potential marriage partners. And discourse of adoption can be tied to the discourse of disaster. Figure 2 depicts the adoptive relationships in one clan on Tanna.

Figure 2 Child Exchange in a Village on Tanna

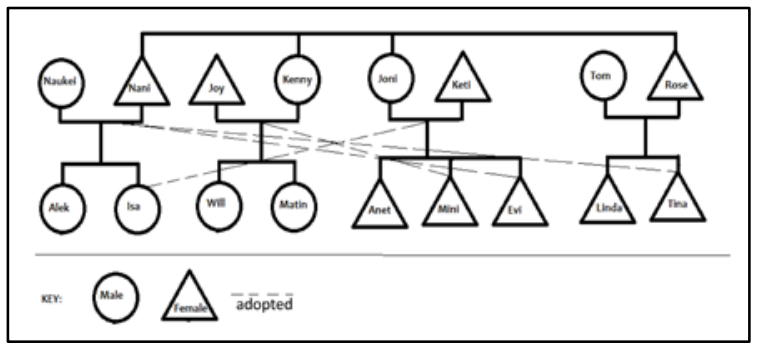

While the concept of reciprocity/retribution is endemic to Melanesian logic, a conservative hermeneutic of the New Testament is consistently inimical to this worldview. To be sure, retribution is a biblical theme notably found in the imprecatory psalms. But imprecation and retribution are best understood in the Old and New Testaments as a prerogative and action of God, in His timing and by His own mysterious methods. Dependence upon the promise that God "will get revenge and pay them back" (Deut. 32:35, NET) removes the need for humans to take retribution into their own hands (D. Nehrbass 2013). Due to the New Testament's ethic of grace (that is, free gifts), many missionaries proscribed the practice of child-swapping (K. Nehrbass 2012, 159). And, of course, God initiated no "exchange" with Satan when He adopted us into His family.

The tension between biblical "turning the other cheek" (Matt. 5:39) and "giving the extra tunic" (Matt. 5:40) on the one hand, and the Melanesian ideal of reciprocity on the other, produces continual cognitive dissonance for Christian families on the Island. As the exchange of children is discouraged, some families have been innovative in finding alternative "payments" to the wife's parents, but to varying degrees of success. Since the gift of a human being is never fully reciprocated without an adoption, hostilities toward the denomi- 
national rules about "child swapping" remain latent; and they are resurrected in times of crisis, such as sickness, death or hurricanes (K. Nehrbass 2011, 460461).

The notion of "child swapping" also severely challenges global sensibilities. The Hague Convention explicitly requires that "The consents have not been induced by payment or compensation of any kind" ("Hague Convention"). It is with this deeply embedded taboo of reciprocity that many Westerners approach the subject of adoption.

\section{Exchange of goods}

Just as "child swapping" is highly desirable in Vanuatu, but highly suspicious in many other contexts, perspectives of any other gift-giving at the time of adoption can vary greatly depending on cultural patterns.

The ceremonial arrangement of adoptive relationships is accompanied by an exchange of goods in both Tanna and Rah. On Rah, the birth parents give small gifts to the adoptive parents. "The prestation includes natamage or natabobo-a cloth for carrying the infant-as well as soap and some cash . . . about \$5 US" (Smith 2012, 2). Since the responsibility of the birth parents ends at this point, there are no future exchanges focused on the adoptive relationship. Social life continues to involve exchanges of kastom goods, but they are not outwardly displayed as being in relation to the adoptive relationship that was formed, as this would jeopardize the anonymity of the birth parents.

On Tanna, the adoptive and biological parents exchange gifts of kava, cloth, mats and baskets. More significantly, the gift-giving continues on special occasions for years, as the biological parents maintain an open relationship with the adoptive parents.

Such exchanges of goods at the time adoptions are arranged should not be surprising: Gift-giving is essential to kastom in Melanesia. The reason that exchanging of goods enters into a discussion of international adoption is that international law and court-arranged adoptions in Vanuatu strictly forbid the exchange of goods. When ni-Vanuatu families see international adoption as an extension of kastom adoption, they understandably foresee one or more opportunities for exchanging goods as a way of sealing the deal. However, paradoxically, such an exchange would automatically endanger the adoption from a legal standpoint. When Australians Warren and Judy appeared in court to adopt Josiah from a Tannese family, the ni-Vanuatu uncle asked the couple for a truck in exchange. The judge explained to the uncle, "We don't swap children for a truck." What seemed logical to the court was illogical within kastom, and vice versa.

\section{Expatriate Adoption in Vanuatu}

We have established that norms for establishing adoptive relationships in Vanuatu are widely divergent from practices of expatriate adoptions. Our thesis is that these norms are very divergent because the fundamental purpose for adoption in the Pacific is at odds with western purposes. Traditionally, adoption in the West has been a mixture of resolving infertility and caring for children who have no parents, as well as protecting children from abusive or neglectful parents. However, in Vanuatu, those are marginally recognized purposes for adoption compared to the central purpose of strengthening social relationships. While western and ni-Vanuatu purposes for adoption are divergent, they both have biblical basis. Scripture calls us to care for the orphan (Psalm 10:14; James 1:27). Scripture also encourages the strengthening of social relationships like Pastor John, in the beginning of this article, wished to extend toward George and Briana Chesterton. NiVanuatu conceptualizations of adoption are meant to foster scriptural values such as unity (John 17:23; 1 Cor. 1:10), peace (Matt. 5:9), trust (Prov. 11:13; Col. 3:9$10)$, and, in fact, love (1 John 4:7-8).

Therefore, if expatriates and ni-Vanuatu wish to successfully arrange adoptions, they will not only need to align the norms, but also learn to see the value in each other's purposes for adoption. Specifically, expatriates would need to view adoption not as being about social action or mitigating infertility, but as a pathway for fostering stronger bonds with South Pacific communities. And Pacific Islanders would need to understand that Westerners are particularly motivated by caring for the children who are "most in need."

A case of adoption from Tanna which the Vanuatu supreme court called "inhumane" serves to illustrate the disconnect between kastom and western conceptualizations of adoption. In November 2013, a taxi driver on Tanna noticed a rolled-up mat obstructing the road, but decided to drive over it rather than avoid it. Tragically, a seven-year-old girl was asleep in the mat. A man who was riding in the front seat of the truck was a relative of the girl, and he later adopted out one of his children to the bereaved family (Ewart 2013) as "restorative justice". The court and news agency expressed surprise that the taxi driver himself (a father of six) did not relinquish one of his own children. But in this case, the transaction was between relatives, so it did not entail the removal of a child from her social network, just a slight repositioning within her network.

We have shown how ni-Vanuatu adoption and inter-country adoption vary in multiple ways. Table 1 (below) gives a summary of how the six variables we have discussed in this article vary not only within Vanuatu, but also contrast with internationally sanctioned norms for adoption. 
Table 1

Comparing Kastom Adoption to Expatriate Adoption

\begin{tabular}{|l|c|c|c|c|c|c|c|}
\hline & Disclosure & $\begin{array}{l}\text { New Land } \\
\text { Rights }\end{array}$ & Permanent & $\begin{array}{l}\text { Exchange } \\
\text { of Child } \\
\text { Expected }\end{array}$ & $\begin{array}{l}\text { Jural } \\
\text { Exclusive }\end{array}$ & $\begin{array}{l}\text { Goods } \\
\text { Exchanged }\end{array}$ & $\begin{array}{l}\text { Hague- } \\
\text { Eligible } \\
\text { (need) }\end{array}$ \\
\hline Kastom Tanna & + & + & + & + & - & + & - \\
\hline Kastom Rah & - & + & + & - & + & + & - \\
\hline $\begin{array}{l}\text { Transferred wet } \\
\text { nurse (death of } \\
\text { mother) }\end{array}$ & + & + & - & - & - & + \\
\hline $\begin{array}{l}\text { Transferred } \\
\text { (infertile) }\end{array}$ & + & + & + & - & - & + & - \\
\hline $\begin{array}{l}\text { Surrendered } \\
\text { (divorce) }\end{array}$ & + & - & - & - & - & - & - \\
\hline $\begin{array}{l}\text { Transferred to } \\
+ \text { 1 Gen (death of } \\
\text { mother) }\end{array}$ & + & - & - & - & - & - & + \\
\hline $\begin{array}{l}\text { International } \\
\text { (eg. Hague) }\end{array}$ & $+/-$ & + & + & - & + & & - \\
\hline
\end{tabular}

As expatriates engage in discussions about adoption with ni-Vanuatu, and as the national courts work out legislation, they must be aware of how kastom adoptions differ from western ideals. Specifically, western Christians are increasingly seeing adoption as a ministry.

\section{Adoption as a Ministry}

Many Christians refer to their motivation to adopt as a sense of calling from God. For some, this calling is an emotional or intuitive experience that is deeply personal (i.e, "I feel called to adopt"). Others recount their decision to adopt as a broader requirement for God's people. They see in Scripture a "biblical mandate" to care for the orphan, which includes adoption. Below are some key verses that underscore this biblical mandate (all quotations are from the NIV):

\section{James 1:27}

Religion that God our Father accepts as pure and faultless is this: to look after orphans and widows in their distress and to keep oneself from being polluted by the world

\section{Deuteronomy 10:18}

He defends the cause of the fatherless and the widow, and loves the foreigner residing among you, giving them food and clothing.

\section{Deuteronomy 24:17}

Do not deprive the foreigner or the fatherless of justice, or take the cloak of the widow as a pledge.
4. Deuteronomy 27:19

"Cursed is anyone who withholds justice from the foreigner, the fatherless or the widow." Then all the people shall say, "Amen!"

\section{Job 29:12}

I rescued the poor who cried for help, and the fatherless who had none to assist them.

6. Psalm 10:14

But you, God, see the trouble of the afflicted; you consider their grief and take it in hand. The victims commit themselves to you; you are the helper of the fatherless.

\section{Psalm 10:18}

... defending the fatherless and the oppressed, so that mere earthly mortals will never again strike terror.

\section{Psalm 68:5}

A father to the fatherless, a defender of widows, is God in his holy dwelling.

\section{Psalm 82:3}

Defend the weak and the fatherless; uphold the cause of the poor and the oppressed.

10. Psalm 146:9

The Lord watches over the foreigner and sustains the fatherless and the widow, but he frustrates the ways of the wicked. 


\section{Isaiah 1:17}

Learn to do right; seek justice. Defend the oppressed. Take up the cause of the fatherless; plead the case of the widow.

\section{Jeremiah $5: 28$}

Their evil deeds have no limit; they do not seek justice. They do not promote the case of the fatherless; they do not defend the just cause of the poor.

Why does the Old Testament advocate so consistently for the orphan? Scholars are not in agreement on this. Wolterstorff (2008) believes the plight of the orphan implicates perversions of the legal system. To care for the orphan is to subvert these perversions. Van De Wiele (2016) believes caring for the orphan is a way of enacting chesed "loving kindness.” Both positions are partially true. We would also add that the orphan has inherent dignity, and it is worthwhile to care for orphans, without needing to draw on any additional biblical motifs.

In my (Daniel's) experience with interviewing adoptive parents, they describe their sense of "calling" to adopt as:

1. The desire to make a difference in the life of a child.

2. Fulfilling the Great Commission (making disciples of all nations, by bringing children from another nation into your family, where you disciple them).

3. Fulfilling the Great Commandment to love one's neighbor (loving a child as oneself).

4. An act of obedience to the commands above (biblical mandate to care for the fatherless).

5. An eschatological vision, evocative of Isaiah 43:6-7, "I will say to the north, 'Give them up!' and to the south, 'Do not hold them back.' Bring my sons from afar and my daughters from the ends of the eartheveryone who is called by my name, whom I created for my glory, whom I formed and made" (NIV).

6. A re-enactment of the gospel (God adopted us into his family, and we re-enact this by adopting children into our family).
While the number of international adoptions into US families has sharply declined in the past decade, the interest among Christians in adopting from abroad has not waned. Annual international adoptions numbered over 22,000 in the US in 2004, and by 2012, the number was down to just over 8000 (Voigt \& Brown 2013). By 2018, the number further declined to 4059 ("Intercountry Adoption"). However interest in international adoption as "social action" has simultaneously risen dramatically. Many westerners (including all western participants in this study) see international adoption as a way to get involved in the fight against violence, illness and injustice. The typical adopting family from the United States ${ }^{3}$ is no longer described as "the couple, who have tried unsuccessfully for many years to have children of their own, who finally, with considerable misgivings, have secured a child of unknown parentage from an institutional intermediary" (Carroll 1970, 4). More and more, couples that inquire about international adoption see adoption as a way globally to fulfill our responsibility to love our neighbor. Westerners-often with one or more birth children-are increasingly aware of what Elliott (2012) has termed a "global orphan crisis". Orphan care has become a top social issue especially for evangelical Christians in recent decades, and the interest appears to have significant staying-power (D. Nehrbass 2012, 18). For example, by 2012, US citizens had finalized 756 adoptions through Uganda (a ratio of one adoption per 46,000 people), and 2,894 adoptions through Haiti (a ratio of 1:3,500). This indicates that in the twenty-first century, engaging in international adoption is as much about child welfare as about filling the home with healthy infants. Consider the numbers for six US adoption agencies between 2011 and 2013:

- Of 118 adoptions processed by New Beginnings, 85 families (72\%) had biological children at the time of adoption (Renae Vallas, pers. comm.).

- 28 of 38 (74\%) of families who adopted with Hope's Promise had biological children (Beth Woods, pers. comm.).

- Children of All Nations reported that $50 \%$ of adoptive families had biological children (Snow $\mathrm{Wu}$, pers. comm.).

- Christian Adoption Services processed 61 adoptions through the Philippines, and 74\% of the families already had children in the home. Only

\footnotetext{
${ }^{3}$ This may be different in Europe. Howell (2003), for instance, noted that between 1998 and 2003 in Norway, "almost every adoptive parent" she interviewed dealt with infertility, and adopted to "become a normal family" (469).
} 
$13 \%$ reported that they were infertile (Jenica Cannella, pers. comm.).

- Nightlight Christian Adoptions reports that of 186 adoptions finalized through my (Daniel's) organization between 2011 and 2013, 89 (48\%) parents did not have biological children at the time of placement, and 97 (52\%) already had biological children.

- Generations Adoptions reported that 21 of 35 families $(60 \%)$ already had children at the time of adoption (Cathy Sones, pers. comm.).

The families I (Kenneth) interviewed who adopted from Vanuatu fit this demographic. They are evangelical Christians who have already confirmed their own fertility. Their discourse of adoption has more to do with their faith and sense of religious calling than with a need for receiving a healthy infant to call their own. In one sense, they have chosen to adopt from Vanuatu because they have strong ties to ni-Vanuatu families. However, in another sense, they have assumed that the orphan crisis equally affects all parts of the developing world, as they draw on stories of unwanted babies in the world's least developed countries who have no safety net.

However, tying the global orphan crisis to international adoption can be problematic in Oceania. First of all, children who have lost both parents in Oceania typically have many other classificatory parents who will care for them. Secondly, Pacific Islanders conceive of adoption in entirely different ways than the westerners who would seek to adopt from there. The customary adoption within Oceania does not involve taking a child out of his or her social network, it means keeping the child within it. True, there are occasionally children in Vanuatu who lack basic needs because their extended families neglect to provide care. And the court system and international adoptions can play a significant part in alleviating that care deficit. But it would be erroneous to see adoption in Vanuatu, on the whole, as an institution which exists to meet the needs of orphans or neglected children.

However, there are some places in Oceania with a fomenting orphan crisis. The Pacific Island nation with the most orphans is Papua New Guinea, where one in eight children are orphaned (Mottram 2009). Overall, though, while international adoption as social action is sensible in places like Haiti or Sub-Saharan Africa, it is rarely necessary as an act of child welfare in the Pacific (even if, ironically, that is the primary motivation of certain potential adopters). Adoption, and inter-country adoption, is still certainly viable in the Pacific, but it may not be accurately described as social action.

This may explain why US adoptions from Oceanic nations are quite rare in a time when international adoption is increasingly linked to social action. In fact, the number of children adopted from Oceania by US families is disproportionate to other regions of the world. Table 2 shows US State department figures on finalized adoptions that were classified as "international adoptions" from independent nations in Oceania since 1999. Note that adoptions by expatriates from these nations which were completed as "domestic adoptions" (after long residence periods, described below) are not counted.

Table 2

Number of Finalized Adoptions in the US by Country in Oceania $1999-2019$

\begin{tabular}{|l|c|l|}
\hline Country & $\begin{array}{l}\text { Number of } \\
\text { US } \\
\text { Adoptions } \\
\text { Finalized }\end{array}$ & $\begin{array}{l}\text { Ratio of } \\
\text { Adopted to } \\
\text { Population }\end{array}$ \\
\hline $\begin{array}{l}\text { Federated } \\
\text { States of } \\
\text { Micronesia }\end{array}$ & 0 & 0 \\
\hline Fiji & 0 & 0 \\
\hline Kiribati & 1 & $1: 100,000$ \\
\hline $\begin{array}{l}\text { Marshall } \\
\text { Islands }\end{array}$ & 73 & $1: 700$ \\
\hline Nauru & 0 & 0 \\
\hline Palau & 5 & 0 \\
\hline $\begin{array}{l}\text { Papua New } \\
\text { Guinea }\end{array}$ & 121 & $1: 1,400,000$ \\
\hline Samoa & 0 & 0 \\
\hline $\begin{array}{l}\text { Solomon } \\
\text { Islands }\end{array}$ & 2 & $1: 1,600$ \\
\hline Tonga & 0 & 0 \\
\hline Tuvalu & & $1: 125,000$ \\
\hline Vanuatu & & \\
\hline
\end{tabular}

(Bureau of Consular Affairs, 2019) ${ }^{t}$

\section{Case Studies in Adoption:}

\section{American Couple Adopts a Baby from Ambrym}

Beau and Anna describe adoption in Vanuatu as a Christian ministry. They had heard several stories about the births of unwanted children at Port Vila's Central Hospital, and became alarmed. An expatriate in the

\footnotetext{
" https://travel.state.gov/content/travel/en/Intercountry-Adoption/adopt_ref/adoption-statistics-esri.html?
} 
capital city learned of their concern, and connected them with an employee at the hospital who would identify one of these babies in need of care. Within months, they heard of Susan, an unmarried woman from Ambrym, who had become pregnant while living in Port Vila. She planned to use the hospital's support system to place her child for adoption.

Beau and Anna met Susan, and discussed adopting the baby. They filed the paperwork with the court and waited. The main obstacle that Vanuatu's legal system presented them was establishing the name of the biological father, and they were ultimately unable to do so. Seven months after paying a small court fee, they had a court date. Beau said that the judge's main concern was to make sure the mother knew that she would "never see the child again." That is, the court assumed permanence and jural exclusivity; but the nijudge likely understood that within kastom, adoptions are not necessarily permanent or exclusive. (In reality, since Beau and Anna are residents of Port Vila, they have maintained a casual relationship with Susan and her extended family).

The judge also asked Beau and Anna, "Has there never been any exchange of goods?"-another sharp contrast to the kastom adoptions. Beau confirmed that there had been no payment. At that point, the court produced a single-page adoption notice, and the judge informed Beau and Anna that they could give the child a new name.

\section{Australian Family Adopts Three Ni-Vanuatu Babies}

Warren and Judy are Australians who have lived in Vanuatu on two occasions over the past nine yearsboth times they stayed in Vanuatu for about three years. As with Beau and Anna, Warren and Judy are motivated to engage in adoption as a way of mitigating social problems. Warren told me,

There are many babies in Port Vila who are unwanted by their mothers, but who have a safety net. But some mothers leave their babies in a pit toilet. Others are left in the ocean. I've heard many stories like this. The Daily Post said that $80 \%$ of the women in jail are there for killing their own children. One woman on Santo had five or six kids, and killed her seventh.

Warren and Judy have been active in this arena. They have completed the adoption process through the Vanuatu courts for three children, but are still establishing Australian citizenship for all three. Warren explained to me,

In all three cases, the parents approached us. Actually, we've been asked [to adopt] six times, but we said no three of those times ... In each case, we asked the mother and her extended family, "What was your motivation? If your motivation is because you want to get something, we're not interested. We're not going to buy you a truck. If you want your child to have opportunities that he wouldn't have otherwise, that's why we would like to adopt."

Warren and Judy's first adoptive child is Jeremiaha boy from Tanna whose mother was unwed. Their second is Ariela, whose mother is also from Tanna. The father was from a different island, and refused to claim responsibility. Ariela's mother lives in Port Vila, and visits Warren and Judy and Ariela every four to six weeks. Their third adoptive child is from Ambae island-a girl named Milani. Warren and Judy already knew Milani's mother, because she had served as their maid before giving birth. She continues to see her mother regularly. Warren told me,

We maintain contact with the families . . . if they get older and want to stay connected with their birth family . . . Jeremiah is legally ours, but we want to maintain a contact with the family. But if the family says, "You have to do this" we politely say "No, we'll make this decision."

Adoption-an action which so easily embodies kastom as the most precious exchange of resources, changes definition and significance when expatriates enter the picture. A taxi driver warned Warren and Judy, "You know you have to give Jeremiah back if the extended family asks for him.” I (Kenneth) don't think the taxi driver was negating the legality of Warren and Judy's adoption; he was advising them that they have crossed cultures, and ni-Vanuatu views of adoption, while not homogenous, are bound to differ from the views of Australians. The taxi driver's unfamiliarity with the jurisdiction of the court underscores the clash of views.

\section{Conclusion}

We suggest that the main reason intercountry adoptions from Oceania are rare is neither political nor financial; rather it is rooted in competing ideals regarding the purpose of adoption. There is a serious divide between "stranger adoption" practiced at the international level, and the "relative adoption" found in Oceania. Westerners tend to desire a bit of anonymity in everything they do; they also expect jural exclusivity; and they require the adoption process to be finalized. In contrast, when ni-Vanuatu enter into adoption negotiations, they hope that the process will never be completely finalized (which would mean the death of 
the relationship). The process is meant to create a relationship, not conclude one.

Kastom adoption is way for ni-Vanuatu to assert their identity, as it is tied to land rights, strengthens alliances, and encompasses the most precious exchange of resources. Interestingly, engaging in international adoption is increasingly a way for Christians (as those who participated in this study) to assert their own identity, as adoption is the ideal symbol of Christian concepts like rebirth and second chances. In fact, international adoption in many church contexts is not carried out solely at the family level. Church bodies are identifying with the orphan care movement as they collectively fund international adoptions for one or more families within the congregation.

While the ambiguities and competing ideals regarding adoption at a local and international level pose a challenge, expatriates and ni-Vanuatu are successfully negotiating adoptive relationships. Some expatriates who have deeply established ties in Vanuatu find the possibility of adoption to be intriguing, but also express concerns that the process of kinning would lead to a crisis of identity for the adoptee. The two expatriate families who have adopted children have not had custody of their adoptive children long enough for them to report whether these concerns about kinning have become manifest for their own adoptive children.

The bifurcation of stranger adoption and relative adoption can be extended to many other parts of the world. Christians who engage in adoption as Christian ministry need to be aware of the variegated perceptions and expectations related to adoption.

\section{References}

Brady, I. (ed.) 1976. Transactions in Kinship: Adoption and Fosterage in Oceania. Honolulu, HI: University Press of Hawaii.

Brueggemann, W. 2002. The Land: Place as Gift, Promise, and Challenge in Biblical Faith (2nd ed.). Minneapolis, MN: Fortress Press.

Carroll, V. 1970. Adoption in Eastern Oceania. Honolulu, HI: University Press of Hawaii.

Elliott, D. 2012. The Global Orphan Crisis: Be the Solution, Change your World. Chicago, IL: Moody.

Ewart, R. 2013. "Vanuatu Court Condemns Child Compensation." Retrieved December 15, 2013, from http://www.radioaustralia.net.au/international/radio/progr am/pacific-beat/vanuatu-court-condemns-childcompensation/1231496.

Goody, J. 1969. Adoption in Cross-Cultural Perspective. Society and History 11(1):55-78.

Nehrbass and Nehrbass, Social Transactions or Christian Ministry
"Hague Convention on Protection of Children and Cooperation in Respect of Intercountry Adoption." Article IV (3). Accessed Nov 5, 2019 from https://www.hcch.net/en/instruments/conventions/fulltext/?cid=69.

Howell, S. 2003. Kinning: The Creation of Life Trajectories in Transnational Adoptive Families. Journal of the Royal Anthropological Institute 9(3): 465-484.

"Intercountry Adoption." 2019. Accessed Nov 5, 2019 from https://www.adoptioncouncil.org/blog/2019/03/fy2018intercountry-adoption-report-released.

Katz, S.\& Katz, D. 2012. Adoption Laws in a Nutshell. St Paul, MN: West Law School.

Kim, K. S. 2014. Another Look at Adoption in Romans 8:15 in Light of Roman Social Practices and Legal Rules. Biblical Theology Bulletin 44(3):133-143. https://doiorg.ezproxy.biola.edu/10.1177/0146107914540488

Lindstrom, L. 1985. Personal Names and Social Reproduction on Tanna, Vanuatu. Journal of the Polynesian Society 94:27-45.

Miller, V. 2015. Mediations for Adoptive Parents. Harrisonburg, VA: Herald Press.

Montgomery, M., \& Powell, I. 2018. Saving International Adoption. Nashville, TN: Vanderbilt University Press.

Mundhenk, N. A. 2008. Adoption: Being Recognized as a Son. The Bible Translator (Ap, O Practical Papers) 59(4):169-178.

Nehrbass, D. 2012. How the Christian Orphan Care Movement Will Have Staying Power. Adoption January (1):18.

Nehrbass, D. 2013. Praying Curses: The Therapeutic and Preaching Value of the Imprecatory Psalms. Eugene, OR: Wipf and Stock.

Nehrbass, K. 2011. Dealing with Disaster: Critical Contextualization of Misfortune in an Animistic Setting. Missiology 39(4):459-471.

Nehrbass, K. 2012. Christianity and Animism in Melanesia: Four Approaches to Gospel and Culture. Pasadena, CA William Carey Library Press.

Rivers, W. H. R. 1914. The History of Melanesian Society. Vol. 1. Cambridge: Cambridge University Press.

Scheffler, H. W. 1970. Kinship and Adoption in the Northern New Hebrides. In Adoption in Eastern Oceania. V. Carroll, ed. Pp. 369-389. Honolulu, HI: University of Hawai'i Press.

Schoenberg, M. W. 1964. St. Paul's Notion on the Adoptive Sonship of Christians. The Thomist 28(1): 51-75. 
Smith, D. 2012. "Adoption in Mota Lava." Paper presented at Summer Institute of Linguistics. Port Vila.

Tonkinson, R. 1982. National Identity and the Problem of Kastom in Vanuatu. Mankind 13:306-315.

Trompf, G. 1994. Payback: The Logic of Retribution in Melanesian Religions. New York: Cambridge.

United_States_Census_Bureau. 2012. Households and families. Retrieved December 31, 2013, from http://www.census.gov/prod/cen2010/briefs/c2010br14.pdf.

Van De Wiele, T. 2016. What Rights Get Wrong about Justice for Orphans: An Old Testament Challenge to a Modern Ideology. Studies in Christian Ethics 29(1):6983. https://doi.org/10.1177/0953946814565986.

Voigt, K., \& Brown, S. 2013. "International adoptions in Decline as Number of Orphans Grows." CNN World. Retrieved December 13, 2013, from http://www.cnn.com/2013/09/16/world/internationaladoption-main-story-decline/.

Wolterstorff, N. 2008. Justice: Rights and Wrongs. Princeton, NJ: Princeton University Press.

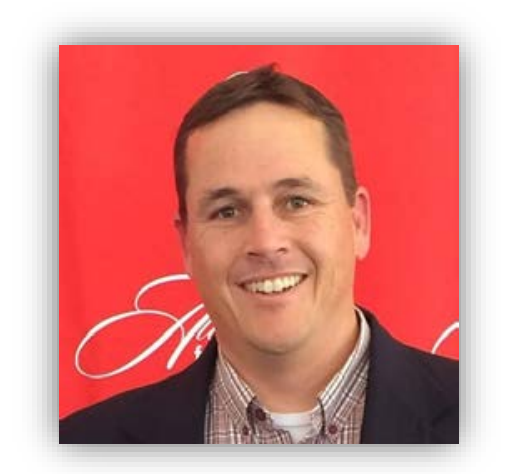

Kenneth Nehrbass, Ph.D., is an associate professor of Intercultural Studies (ICS) at Cook School of Intercultural Studies, Biola University, where he directs the MA in ICS program. He has authored more than 50 academic publications including books, articles, reviews, a multi-language dictionary and vernacular New Testament.

Author email: kenneth.r.nehrbass@biola.edu

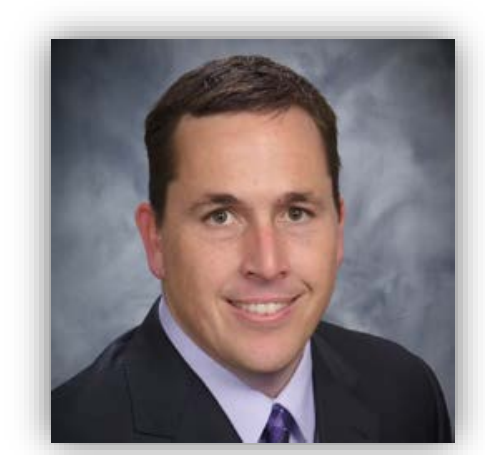

Daniel Nehrbass, Ph.D., is the President of Nightlight Christian Adoptions, home of the Snowflakes ${ }^{\circledR}$ Embryo Adoption program. He has worked as a pastor, professional counselor, and adjunct professor of biblical studies at Biola University. He is also a published author of four books and numerous articles in adoption and religious magazines. Dan is a board member of Every Child Has a Name, the National Christian Adoption Fellowship, A Helping Hand, and on the organizing committee of Adopted for Good.

Author email: daniel@nightlight.org 